\title{
Factors Influencing Online Shopping Intention: A study among online shoppers in Oman
}

\author{
Hamed Khalfan Hamed AL-Shukri \\ Udayanan
}

To Link this Article: http://dx.doi.org/10.6007/IJARBSS/v9-i3/5736

DOI: $\quad 10.6007 /$ IJARBSS/v9-i3/5736

Received: 06 Feb 2019, Revised: 23 Feb 2019, Accepted: 26 March 2019

Published Online: 04 April 2019

In-Text Citation: (AL-Shukri \& Udayanan, 2019)

To Cite this Article: AL-Shukri, H. K. H., \& Udayanan. (2019). Factors Influencing Online Shopping Intention: A study among online shoppers in Oman. International Journal of Academic Research in Business and Social Sciences, 9(3), 691-709.

\section{Copyright: (C) 2019 The Author(s)}

Published by Human Resource Management Academic Research Society (www.hrmars.com)

This article is published under the Creative Commons Attribution (CC BY 4.0) license. Anyone may reproduce, distribute, translate and create derivative works of this article (for both commercial and non-commercial purposes), subject to full attribution to the original publication and authors. The full terms of this license may be seen at: http://creativecommons.org/licences/by/4.0/legalcode

\section{Vol. 9, No. 3, 2019, Pg. 691 - 709}




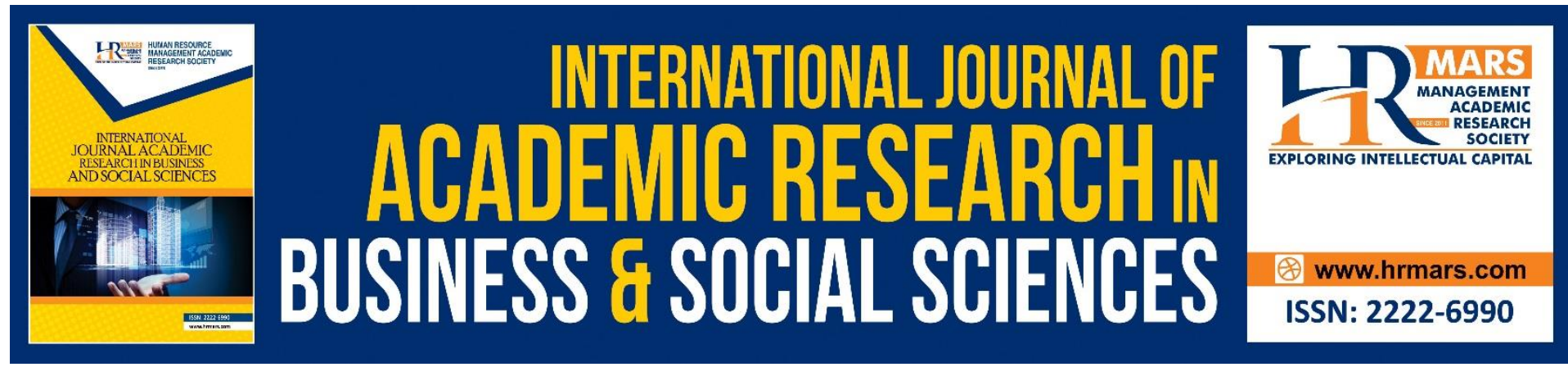

\title{
Factors Influencing Online Shopping Intention: A study among online shoppers in Oman
}

\author{
Hamed Khalfan Hamed AL-Shukri
}

Software Engineer, Muscat, Oman, Email: hamed.alshukri@qomrah.om

\section{Udayanan}

Assistant Professor, Faculty of Business Management, Majan University College, Muscat, Oman, Email: pappusamy.udhaynan@majancollege.edu.om

\begin{abstract}
The role of E-commerce is inevitable in today's business and the diffusion of the internet has spurred the growth of online shoppers (MENA Bytes, 2019). Oman ranks next to Saudi Arabia in online shopping, however, the e-commerce market in Oman in just $1 \%$ of its total sales. The objective of the research is to study the factors influencing online shopping intention in Oman focusing the B2C transactions. Using the literature review, four factors (web trust, perceived risk, privacy protection, and user experience) were identified as the determinants of Online shopping intention. The relationship between these four factors and online shopping were tested using the data collected from 104 respondents through a self-administrated questionnaire using an online survey. The data were analyzed using SEM approach. The study revealed that web-trust, perceived risk, privacy, and user experience determined consumers' online shopping intention. The study outlines the significance of the determinants of consumers' online shopping intention and the need for e-commerce players to explore these determinants to increase the consumers' online shopping intention.
\end{abstract}

Keywords: Online Shopping Intention, Ecommerce, B2C Online Shopping Intention

\section{Introduction}

The Middle East and North Africa region (MENA) is witnessing rapid growth in e-commerce and the year 2022, the market volume is expected to touch US\$2 8.5billion (MENA bytes, 2019). Online shopping is a form of e-commerce. Many businesses are engaged in online shopping. Online shopping is a narrow scope of e-commerce where the customer buys products or services from a seller through an electronic medium such as the Internet (Qureshi, Fatima, \& Sarwar, 2014). Those websites specialize in online shopping are called web-stores, online stores, online storefronts, and virtual stores (Shah \& Rao, 2014). The popularity of online shopping keeps increasing, especially in the MENA region, because of the advantages it offers to both consumers and businesses. The benefits customers gain from online shopping are the convenience, cost-efficient, comparing products of different stores (Forte,2015), 24 hours 7 days a week shopping, anytime anywhere shopping, time efficient, detailed information about products (Rodgers, 2010). The online shopping in Oman is steadily growing since 2012 and the estimated number of Internet users of the total population in Oman is $71.1 \%$ as of 2016 compared to $70.8 \%$ in 2015 and $70.2 \%$ in 2014 (Internet live stats, 2016). 
Oman ranks next to Saudi Arabia in online shopping (Sheikha, 2019). However, the e-commerce market in Oman is $1 \%$ of the total sales and the biggest challenge is changing the mindset of the people (Mordorintelligence.com, 2017). The growth of the internet and e-commerce has led to many pieces of research focusing on online shopping intention, to understand the factors that determine the online purchase. Most of the studies on the online shopping intention were largely based on American, European and Asian countries. Middle Eastern countries in general and Oman, in particular, lack this type of studies, although online shopping in the Middle East is growing at a fast pace. The objective of the research is to study the factors influencing online shopping intention in Oman focusing the $\mathrm{B} 2 \mathrm{C}$ transactions.

\section{Literature Review}

Different studies have been conducted to identify the factors affecting customers' online shopping intention.

\section{Web Trust}

Consumers tend to share their experiences about products and services with each other, which is referred to as word of mouth (WOM). Advancement in technology offers new ways for consumers to share their experiences, opinions, recommendations, and suggestions online through virtual communities, sellers' websites, blogs, and online forums. An online form of WOM, electronic word of mouth (eWOM), is defined by Strauss and Hill (as quoted in Racherla, 2008, p. 25) as "any positive or negative statement made by potential, existing or former customers about a product or company, and which is made available to a multitude of people and institutions via the Internet and other ecommerce channels". Kim and Song (2010) confirmed that eWOM had a positive influence on online shopping intention. In the light of eWOM, Online Consumer Reviews (OCR) positively influence consumers' trust in the sellers and, therefore, influence online shopping intention. Negative reviews lead to lower sales ratio whereas positive reviews lead to higher sales (Köksal \& Penez, 2015). Sam and Sharma (2015) emphasized that OCR was the second most important factor in driving consumers toward the adoption of online shopping.

Virtual communities, such as Facebook, Twitter, Instagram, Google Plus and alike, influence consumers' willingness to shop online. Consumers receive recommendations and suggestions from their friends, family members, and co-workers. Another eWOM platform is online blogs, which, consumers consider as a credible source of information. A repeated interaction between bloggers and blog readers, trust is built, which in turn influences consumers' intention in online shopping (Hsu, Chuan-Chuan,\& Chiang, 2013).

A study by Santos and Fernandes (2011) showed that trust was strongly associated with previous online shopping experience (POSE). The previous online shopping experience positively influenced consumers' intention to shop online (Santos \& Fernandes, 2011; Dai, Forsythe \& Kwon, 2014). Online shopping experience does not only influences consumers' trust and online shopping intention but also influences perceived risk (Dai et al., 2014). On the other hand, because of the nature of online shopping environment, there is no direct interaction between buyers and sellers. This lack of interaction creates an issue for consumers as they cannot check the quality of products physically, and cannot ensure their financial and personal information security (Sun and Yang, as cited in Shadkam, 2012). Unless a trust is built between buyers and seller, all these kind of issues contributes to building barriers that affect consumers' online shopping intention. Previous studies showed that trust positively influences consumers' intention to shop online and is influenced by other factors like perceived risk, web security, online privacy and user experience (Wu \& Ke 2015; Topaloğlu, 2012; Shadkam,2012; Racherla,2008; Kim \& Son, 2010; Hsu et al., 2013; Hsu, Chuang, \& Hsu, 2014; Santos \& Fernandes, 2011). Trust is the "readiness of one side to be susceptible to actions of another one, 
which will perform tasks on behalf of the trustor, disregarding any circumstance of screening any private data" (Mayer, Davis, \& Schoorman as cited in Köksal and Penez 2015, p. 29). Chen and Tan (as cited in Matic \& Vojvodic, 2014, p. 59) added that consumers' perceived trust in the virtual environment depends on the privacy and security of their personal information. Internet shoppers are concerned about the security of their information as it can be used for malicious purposes, especially when customers are revealing their financial and personal information (Topaloğlu,2012). Shadkam (2012) concluded that an increase in customers' trust in online shopping is a result of an increase in the sellers' credibility, quality of information, and consideration of security and privacy. In the case of evaluating the relationship between trust and online shopping. Trust is also positively related to consumers' intention to shop online (Hsu et al.,2014; Wu and Ke 2015).

Hypothesis 1: Web trust positively influences online shopping intention

Hypothesis 2: Previous online shopping experience; Web trust; and Physical interaction with the shoppers determine Web trust.

\section{Perceived Risk}

Many researchers had studied the effects of perceived risk on the intention to shop online (Vinod, Subhash, Kumar, \& Shameem, 2015; Kim \& Byramjee 2014; Kim \& Lennon 2013; Dai et al., 2014; Pi and Sangruang 2011). Researches have shown that perceived risk is affected by factors such as trust (Hsu et al., 2013; Hsu et al., 2014; Kim and Song 2010). Majority of customers perceive risks while engaging in online shopping (Kim \& Byramjee 2014; Vinod et al., 2015). Therefore, customers were risk-averse rather than risk-taking. Several researchers studied perceived risk from a multidimensional perspective. Almousa (2011) studied the influence of perceived financial, performance, physiological, time and privacy risks on the intention to shop online. Pi and Sangruang (2011) studied the influence of perceived convenience, financial, physical, physiological, performance, social and time risk on the frequency of online shopping. Dai, Forsythe, and Kwon (2014) investigated the influence of perceived performance, financial and privacy risks on the online shopping experience. Vinod et al. (2015) examined the influence of perceived performance, physiological, social, financial, online payment and delivery risk on purchase intention. Although the results vary depending on the dimensions measured, perceived risk influenced the online shopping intention.

\section{Perceived Risk: Types}

The convenience risk is defined as the risk associated with the difficulty in submitting an order or delivering the right products without any delay (Pi \& Sangruang 2011). It is worth mentioning that Hong and Cha (as quoted in Vinod et al., 2015, p. 238) defined the risk related to product delivery as a delivery risk. The quality of the delivered products, the cost of shipping and the time required to deliver products are major concerns to customers. The financial risk is defined as the risk associated with the fear of loss of money due to overpriced products, credit card fraud, shipping costs and other unexpected, hidden costs (Dai et al., 2014; Pi \& Sangruang 2011;). The performance risk, also known as product risk and quality risk, is defined as the risk associated with the possibility of not meeting the expected level of performance, or purchasing fake or defective products as customers cannot physically examine and test the products (Dai et al., 2014; Pi and Sangruang, 2011). Sam and Sharma (2015) in their research stated that product quality is one of the concerns that consumers perceive while shopping online. According to their study, consumers prefer to shop in physical retail stores rather than online when to purchase tangible, expensive products, as they want to check the quality of products prior to purchase. These products include clothing, electronics, groceries, and jewellery. On the other hand, digital goods like movies, games, and music were acceptable to consumers to 
purchase online due to its intangibility form. Time risk is associated with the time wasted in looking for a reliable online store, searching for products and processing transactions (Pi \& Sangruang, 2011).

Hypothesis 3: Perceived risk negatively influences the online shopping intention.

Hypothesis 4: Perceived risk is determined by financial risk; convenience risk; time risk; and performance risk.

\section{Web Security and Privacy Protection}

Consumers engaging in any type of online activity are exposed to various security and privacy issues. Cybercriminals target websites with a high number of users to steal their financial and personal information, and travel websites. A report by World Pay (2016) confirmed that $31 \%$ of customers were concerned about the privacy of their details saved in their online profiles. This indicates that web security and online privacy are critical factors that influence consumers' intention to shop online as evidenced by previous researchers (Mubarak, Zyngier, \& Hodkinson, 2013; Mpinganjira, 2015; Sam \& Sharma 2015; Shah \& Rao 2014; Shadkam, 2012; Topaloğlu, 2012; Matic \& Vojvodic 2014). Although several researchers have combined web security and online privacy together in their researches to study online shopping, it is important to note that web security differs in meaning from online privacy. Garfinkel and Spatford (as quoted in Köksal \& Penez 2015, p. 30) described web security as "a set of procedures, practices, and technologies for assuring the reliable, predictable operation of web servers, web browsers, other programs that communicate with web servers, and the surrounding Internet infrastructure". On the other hand, Boritz et al. (as quoted in Mubarak et al. 2013, p. 704) have defined Internet privacy as an "individual's right to access and control their personal information with respect to its collection, use and transfer over the Internet".

Matic and Vojvodic (2014) in their study confirmed that consumers are more likely to make online purchases when they perceive lower security risks. Shadkam (2012) asserted that the owners of online stores should pay attention to the security of their online shopping websites by using advanced technology and network firewalls to secure online transactions against hackers and cybercriminals. Additionally, in terms of privacy protection, Mpinganjira (2015) stated that customers have to be assured that their personal and financial information is protected from unauthorized access, and no one may use these details without his or her knowledge. Bernard and Makienko (2011) asserted that a clear privacy policy has the ability to reduce shoppers' privacy concerns and enhance sellers' trustworthiness. Mubarak et al. (2013) concluded that online stores' reputation played a major role in how these stores ensure consumers' security and privacy by securing consumers' data and communication channels, protecting consumers from data loss and corruption, and ensuring to consumers that no one will violate their privacy rights. These concerns arise when it is mandatory to involve consumers' credit card in online transactions.

Hypothesis 5: Better web security and privacy protection is, higher will be the online shopping intention

Hypothesis 6: Web security and privacy protection is determined by a secured payment method; and the risk of exploiting the online user's personal information

\section{User Experience}

Customers' perception toward an online store depends on the users while using the website. As a result, user experience (UX) can be described as the quality of experience a person derives when he or she interacts with a specific design (Knemeyer \& Svoboda 2007). In the case of online shopping, some authors refer to user experience as customer experience, web experience or online experience. Morville (2004) developed a "User Experience Honeycomb" diagram to illustrate the facet of user 
experience. The diagram showed that UX and information included on the website have to be useful, usable, desirable, findable, accessible, credible and valuable. It is important to note that user experience being discussed here differs from aforementioned previous online shopping experience (POSE), in which the later simply means the impressions and emotions formed in the past regarding an online store. A web store's user experience is an important aspect to look into to make the shopping experience as pleasant as possible. UX includes various factors such as its design, functionality, ease of use, usefulness, website speed, shipping and payment process, and information about products and services (Alam \& Yasin 2010; Meera \& Gayathiri 2015; Sam \& Sharma 2015; Shadkam, 2012; Rose, Clark, Samouel, \& Hair, 2012). All these contribute positively to consumers' adoption of online shopping.

Hypothesis 7: Better, the user experience, higher will be the online shopping intention.

Mpinganjira (2015) stated that perceived service quality provided to customers encouraging them to shop online. Ha \& Stoel (as quoted in Mpinganjira 2015, p. 116) used the term service quality to refer to the perceived performance and effectiveness of online stores in terms of what products or services are offered to the customers. Additionally, Parasuraman et al. (as quoted in Mpinganjira 2015, p. 116) have defined e-service quality as 'deeds, efforts or performances whose delivery is mediated by information technology including the web, information kiosks, and mobile devices". Mpinganjira (2015) examined three dimensions related to service quality: platform quality, interaction quality, and outcome quality. Platform quality covers website design, its colours, graphics, page layout and quality of information provided to help customers engage in online purchasing. Interaction quality covers ease of use, website loading speed, user-friendly interface, and easy transaction process. Outcome quality covers the fulfilment of customers' orders and privacy protection. Customers order products online and expect to receive them in time, in good condition and incur less shipping expenses if not free of charge.

\section{Website Design}

Websites are the storefront of online stores. Consumers draw a first impression, good or bad, about the web store, according to its design, organization, and product information provided. Although the design of the website does not have an impact on experienced or repeated customers, it signals the strength of the company (Meera \& Gayathiri, 2015).

Well-designed websites with user-friendly interface rich with images and information about the products have positive effects on customers' satisfaction, which leads customers to shop online (Shadkam, 2012; Alam \& Yasin, 2010). Rose et al. (2012) emphasized that website design and its speed were no longer hold any importance to the customers. Meera and Gayathiri (2015) contradicted the previous study and stressed the importance of the loading speed, as a slow website irritates customers and, thus, leads customers to leave the web store. In fact, Dyn (2015) evidenced that the consumer's trust was affected by the speed and quality of a website's performance. Equally important, the existence of search functionality in a web store enables customers to find things quickly and navigate to the desired products without a hassle, which speeds up the shopping and increases the sales (Meera \& Gayathiri 2015).

\section{Perceived Usefulness and Ease of Use}

Several studies showed that perceived usefulness and perceived ease of use have a positive effect on online shopping (Sam \& Sharma 2015; Wu \& Ke 2015; Kim \& Song 2010; Rose et al. 2012). Hernandez et al. (as cited in Wu \& Ke 2015, p. 88) defined perceived ease of use as "the degree to which a person believes that using a specific technology will not require additional effort." 
Additionally, the same researchers defined perceived usefulness as "the degree to which a potential user believes that the use of a specific tool or device will enhance his or her performance." Consumers perceive the usefulness of an online store in terms of the availability of detailed information about the products sold. In the case of perceived ease of use, convenience, and simple payment process were the most important factors perceived by customers (Sam and Sharma 2015; Wu and Ke, 2015). Based on the above literature, the following hypothesis is deduced:

Hypothesis 8: The web design, the user-friendliness of the website, the e-service quality, and the perceived usefulness of the online shopping determine the user experience.

\section{Methodology}

The research is descriptive in nature. The population of this research was customers who have had previous experience in online shopping. The selected target sample consisted of 104 respondents. The research sample included students and employees from the public and private sector. The questionnaire was developed based on the factors aforementioned in the literature review. Table1details the variables used to construct the questionnaire. Few statements were adopted from Ali (2014) and Mathew (2013) to develop the items of the questionnaire. An online questionnaire using a 5-point Likert scale ranging from 1 "strongly disagree" to 5 "strongly agree" was administered using Survey Gizmo (http://surveyizmo.com). The target respondents were invited to complete the questionnaire anonymously at their convenient time by giving them a special link that redirects the users to the questionnaire. The data was analyzed using SPPS. Table 1 shows the choice of dependent and independent variables.

\section{Table 1}

Choice of Independent Variables and Dependent Variables

\begin{tabular}{|c|c|c|}
\hline DV & $1^{\text {st }}$ order factor (IVs) & $2^{\text {nd }}$ order factor (IVs) \\
\hline \multirow{13}{*}{ Online shopping Intention } & \multirow{3}{*}{ Web Trust } & $\begin{array}{l}\text { Previous online shopping experience } \\
\text { (POSE) }\end{array}$ \\
\hline & & Physical interaction with retail stores \\
\hline & & E- Word of Mouth \\
\hline & \multirow{4}{*}{ Perceived risk } & Financial risk \\
\hline & & Convenience risk \\
\hline & & Time risk \\
\hline & & Performance risk \\
\hline & \multirow[b]{2}{*}{ Security } & Secured payment method \\
\hline & & Misuse of personal data \\
\hline & \multirow{4}{*}{ User experience } & Web design \\
\hline & & Ease of Use \\
\hline & & Perceived usefulness \\
\hline & & E-service quality \\
\hline
\end{tabular}

Source: Author's work

Validity and reliability of the questionnaire

The CFA loadings in table 2 (standardized loadings) indicates that all the items qualify for scale development. The CFA loadings are greater than 0.50 for all the items, which support the construct validity of the instrument. Table 3 shows the measures for composite reliability and convergence 
validity. The composite reliability for all the factors are higher than 0.7 and the AVE for the factors are greater than 0.5 , which proves the reliability and the convergent validity of the instrument. The Maximum shared variance (MSV) is less than AVE; $\operatorname{MaxR}(\mathrm{H})$ is greater than CR; AVE and the square root of AVE are greater than inter-construct correlations which support the discriminant validity of the construct.

Table 2

CFA Loadings for the Constructs

\begin{tabular}{|c|c|c|c|c|c|c|}
\hline Construct & Variables & $\begin{array}{l}\text { Unstandar } \\
\text { dized } \\
\text { loadings }\end{array}$ & $\begin{array}{l}\text { Standardize } \\
\text { d loadings }\end{array}$ & S.E. & C.R. & $P$ \\
\hline \multirow{4}{*}{$\begin{array}{l}\text { Perceived } \\
\text { Risk }\end{array}$} & Financial risk & 0.667 & 0.939 & 0.028 & 23.74 & $0.000 * *$ \\
\hline & Convenience risk & 0.581 & 0.770 & 0.033 & 17.42 & $0.000 * *$ \\
\hline & Time risk & 0.615 & 0.821 & 0.032 & 19.11 & $0.000 * *$ \\
\hline & Performance risk & 0.629 & 0.814 & 0.033 & 18.89 & $0.000 * *$ \\
\hline \multirow{4}{*}{$\begin{array}{l}\text { User } \\
\text { Experience }\end{array}$} & Web design & 0.557 & 0.775 & 0.032 & 17.13 & $0.000 * *$ \\
\hline & Ease of Use & 0.619 & 0.817 & 0.033 & 18.51 & $0.000 * *$ \\
\hline & Perceived usefulness & 0.604 & 0.770 & 0.036 & 16.98 & $0.000 * *$ \\
\hline & E-service quality & 0.599 & 0.796 & 0.034 & 17.83 & $0.000 * *$ \\
\hline \multirow[t]{3}{*}{ Web Trust } & $\begin{array}{l}\text { Previous } \\
\text { shopping } \\
\text { (POSE) }\end{array}$ & 0.418 & 0.752 & 0.026 & 16.00 & $0.000 * *$ \\
\hline & $\begin{array}{l}\text { Physical interaction } \\
\text { with retail stores }\end{array}$ & 0.617 & 0.849 & 0.033 & 18.79 & $0.000 * *$ \\
\hline & E- Word of Mouth & 0.530 & 0.742 & 0.034 & 15.70 & $0.000 * *$ \\
\hline \multirow{2}{*}{$\begin{array}{l}\text { Security } \\
\text { Private } \\
\text { Protection }\end{array}$} & $\begin{array}{l}\text { Secured payment } \\
\text { method }\end{array}$ & 0.590 & 0.769 & 0.037 & 15.80 & $0.000 * *$ \\
\hline & $\begin{array}{l}\text { Misuse of personal } \\
\text { data }\end{array}$ & 0.614 & 0.853 & 0.035 & 17.77 & $0.000 * *$ \\
\hline
\end{tabular}

Source: Author's calculation; ${ }^{* *} p<0.01$ 
Table 3

Model Validity and Reliability Measures for Online Shopping Behaviour

\begin{tabular}{|lllllllll|}
\hline Factors & CR & AVE & MSV & $\operatorname{MaxR}(\mathrm{H})$ & 1 & 2 & 3 & 4 \\
\hline Perceived Risk & 0.90 & 0.7 & 0.428 & 0.928 & 0.838 & & & \\
\hline User Experience & 0.87 & 0.62 & 0.45 & 0.87 & $0.654^{* *}$ & 0.79 & & \\
\hline Web Trust & 0.83 & 0.61 & 0.396 & 0.836 & $0.604^{* *}$ & $0.548^{* *}$ & 0.782 & \\
\hline $\begin{array}{l}\text { Security \& } \\
\text { Private }\end{array}$ & 0.79 & 0.66 & 0.45 & 0.805 & $0.563^{* *}$ & $0.670^{* *}$ & $0.629^{* *}$ & 0.81 \\
Protection & & & & & & & & \\
\hline
\end{tabular}

Source: Author's calculation; ${ }^{* *} p<0.01$

\section{Model Fit Measures}

Table 4 details the model fit. The model fit cannot be estimated with a single measure; instead, various indices have to be interpreted. The indices namely, the RMSEA, CFI, SRMR, P Close, CMIN/DF has been used to assess the model's validity. Chi-square statistics is used as descriptive goodness of fit index. The chi-square value is compared with the expected valued of the sample distribution. A value between 2 and 3 indicates a good model fit (Jöreskog \& Sörbom, 1993). The RMSEA that ranges between 0.05 and 0.08 is considered an adequate fit and a p - close greater than 0.05 indicates a close fit (Browne \& Cudeck, 1993). Standardized RMR "is an overall badness-of-fit measure that is based on the fitted residuals" and values close to zero suggest a good fit (Schermelleh-Engel et al., 2003). As per the various cut-off criteria, the statistics establish the model fit. The CFI index 0.966 is an acceptable fit and the index for SRMR is 0.051, which is a good fit.

Table 4

Model Fit Measures and Cut off Criteria

\begin{tabular}{|l|l|l|l|}
\hline Measure & \multicolumn{2}{l}{ Estimate } & \multicolumn{2}{l|}{ Threshold (cut-off) } & Interpretation \\
\hline CMIN & 158.919 & -- & - \\
\hline DF & 59 & -- & -- \\
\hline CMIN/DF & 2.694 & Between 1 and 3 & Good model fit \\
\hline CFI & 0.966 & $>0.95$ & Acceptable fit \\
\hline SRMR & 0.051 & $<0.08$ & Acceptable fit \\
\hline \multirow{2}{*}{$\begin{array}{l}\text { RMSEA } \\
\text { P Close }\end{array}$} & 0.067 & $<0.06$ & Adequate fit \\
\cline { 2 - 4 } & 0.014 & $>0.05$ & Acceptable \\
\hline
\end{tabular}

Source: Author's calculation

Figure 1

Standardized loadings for the constructs 


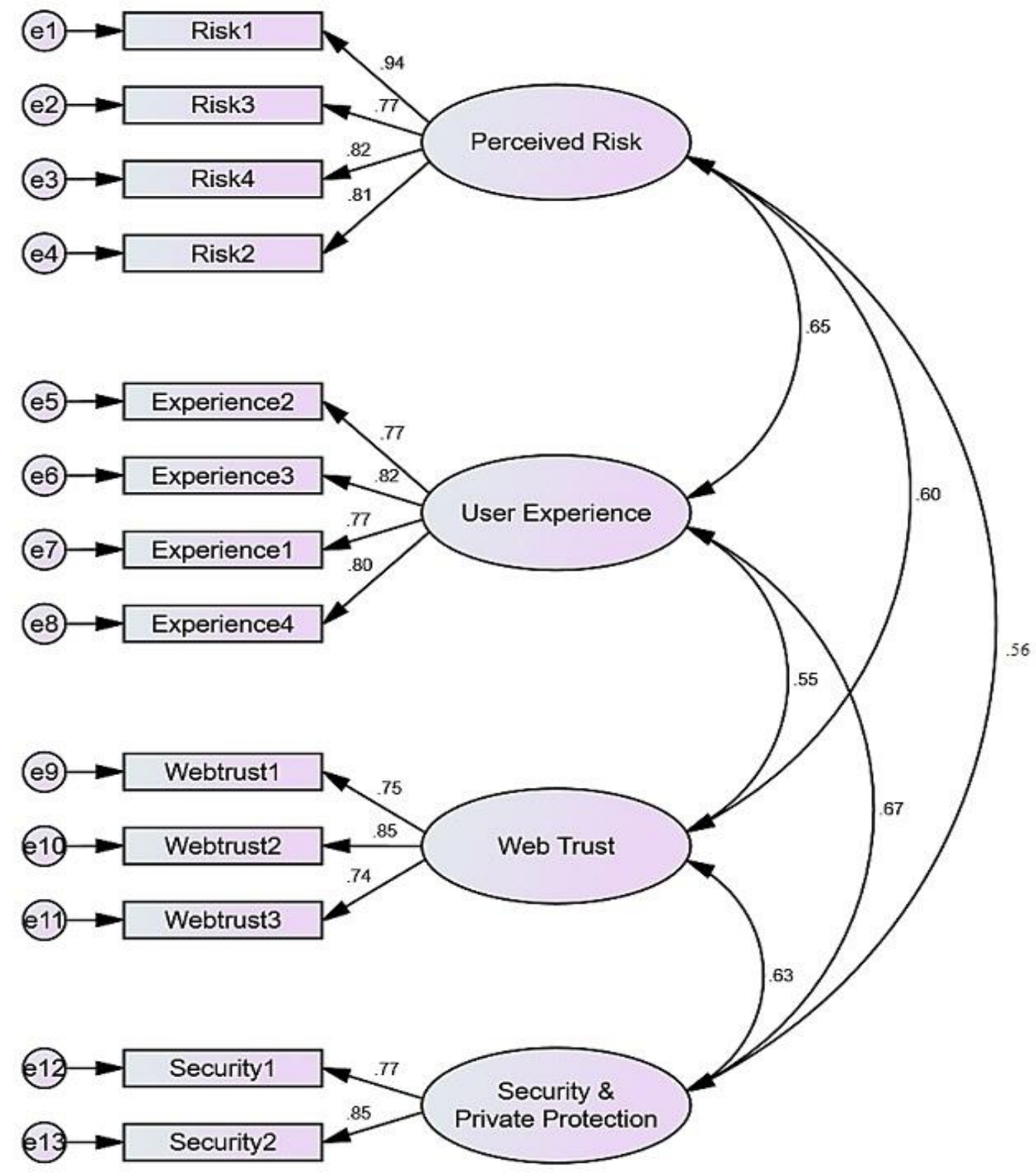

\section{Findings}

A total number of 131 people responded to the questionnaire, out of which 104 responses were valid and usable. Among the 104 respondents, 94.23\% (98) were Omanis, 3.85\% (4) were Arabs (NonOmanis) and $1.92 \%$ (2) were Asians. The sample consisted of 76 males (73.08\%) and 28 females (26.92\%). The majority of the participants (46.15\%) were aged between 30 and 39 years, $28.85 \%$ of the respondents were aged between 25 and 29 years and $3.85 \%$ of the respondents were in between 40 and 49 years. Approximately $12 \%$ of respondents preferred not to reveal the income level. Of the total 104 respondents, the monthly income of $23.08 \%$ of the participants was in-between between 1001 and 1500 Omani Rials.

\section{Validation of the Research Model}

The research model was tested using Structural equation modelling (SEM) using AMOS 21. The table 6 details the fit indices of the model. The fit indices $\mathrm{Cmin} / \mathrm{df}=4.148(\mathrm{Cmin}=282.05, \mathrm{df}=68) ; \mathrm{GFI}=$ 0.904; $\mathrm{AGFI}=0.901 ; \mathrm{CFI}=0.905 ; \mathrm{RMSEA}=0.081$ were with in the acceptable limits and hence the model was established for its fitness. 


\section{Table 5}

\section{Goodness of Fit Statistics}

\begin{tabular}{|l|l|l|}
\hline Statistics & Values & Fit values \\
\hline Chi Square Value (CMIN) & 282.05 & \\
\hline Degree of Freedom (Df) & 68 & \\
\hline Chi Square / Df (CMIN/Df) & 4.148 & 2 to 5 \\
\hline Goodness of Fit Index (GFI) & 0.904 & $>0.9$ \\
\hline Root Mean Square Error of Approximation (RMSEA) & 0.081 & $<0.08$ \\
\hline Adjusted Good of Fit Index (AGFI) & 0.901 & $>0.8$ \\
\hline Comparative Fit Index (CFI) & 0.905 & $>0.9$ \\
\hline
\end{tabular}

Source: Author's calculation

Browne \&Cudeck (1993) study indicates the model fit can be checked by RMSEA, which is less than 0.08 , has a good fit and less than 0.05 has a closer fit. Chin and Todd (1995) study proposed that for the goodness of model fit GFI (Goodness of Fit Index) and NFI (Normed Fit Index) should be above 0.9 and AGFI (Adjusted good-of-fit Index) should be above 0.80. Bentler (1990) study suggest for good model fit CFI (Comparative Fit Index) should be greater than 0.9. The goodness of the final model fit is shown in the above table. Figure 1 shows the standardised loadings for the construct. As per the various fit statistics, the model is a good fit. Figure 2 is the path model for online shopping intention and table 6 shows the standardized loadings of the path analysis.

Figure 2

Path analysis for Online Shopping Behaviour

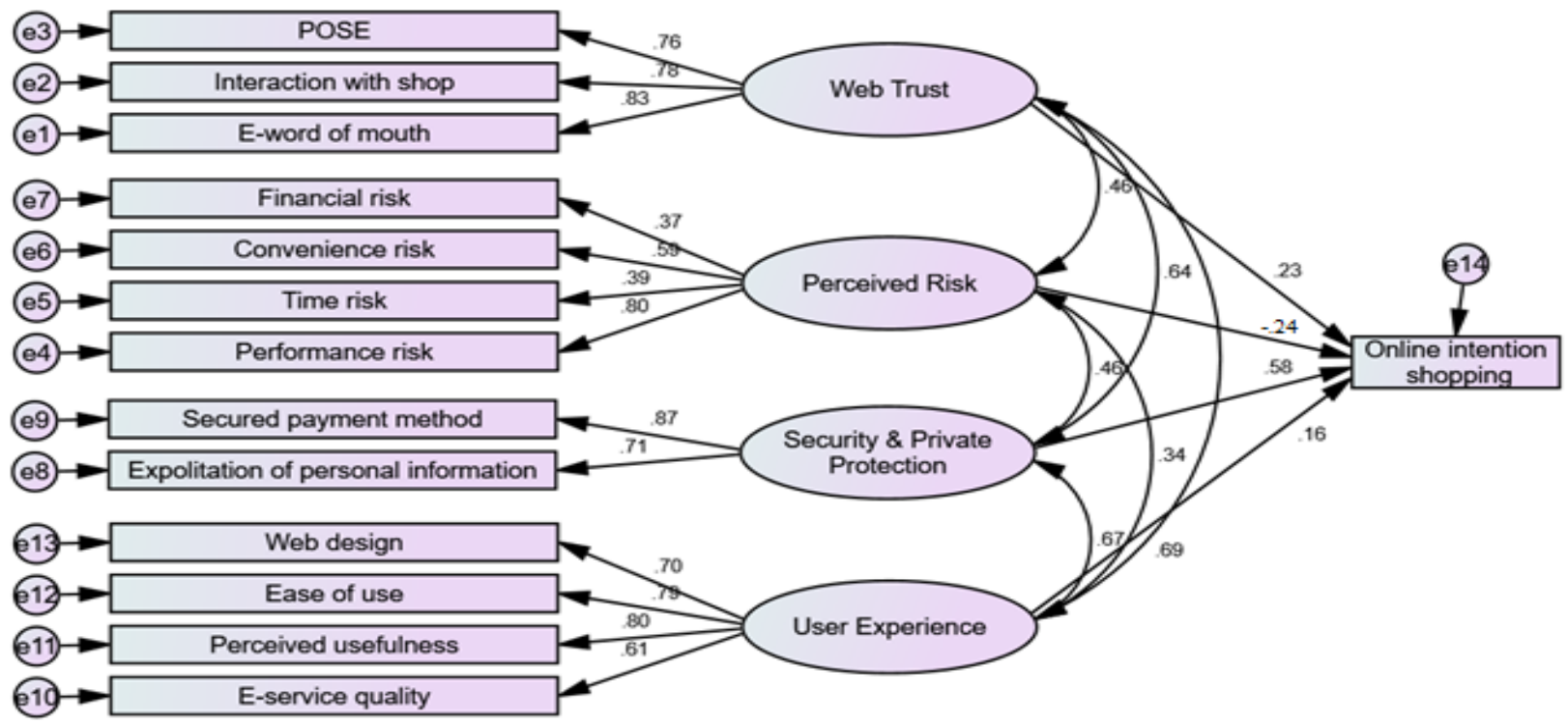


INTERNATIONAL JOURNAL OF ACADEMIC RESEARCH IN BUSINESS AND SOCIAL SCIENCES

Vol. 9, No. 3, March, 2019, E-ISSN: 222 2-6990 ¿ 2019 HRMARS

Table 6

Statistics of the Path analysis for Online shopping Behaviour

\begin{tabular}{|c|c|c|c|c|}
\hline Dependent variables & Independent variables & $\begin{array}{l}\text { Standardized } \\
\text { loadings }\end{array}$ & S.E. & C.R. \\
\hline \multirow[t]{3}{*}{ Web Trust } & POSE & $0.760^{* *}$ & 0.031 & 16.405 \\
\hline & Interaction with shop & $0.780^{* *}$ & 0.035 & 16.988 \\
\hline & E-word of mouth & $0.830 * *$ & 0.032 & 18.544 \\
\hline \multirow[t]{4}{*}{ Perceived Risk } & Financial risk & $0.374 * *$ & 0.040 & 6.438 \\
\hline & Convenience risk & $0.590^{* *}$ & 0.043 & 10.294 \\
\hline & Time risk & $0.394^{* *}$ & 0.043 & 6.815 \\
\hline & Performance risk & $0.796 * *$ & 0.048 & 13.413 \\
\hline \multirow{2}{*}{$\begin{array}{l}\text { Security \& Private } \\
\text { Protection }\end{array}$} & Secured payment method & $0.872^{* *}$ & 0.035 & 19.052 \\
\hline & $\begin{array}{l}\begin{array}{l}\text { Exploitation of personal } \\
\text { information }\end{array} \\
\end{array}$ & $0.712^{* *}$ & 0.036 & 14.909 \\
\hline \multirow[t]{4}{*}{ User Experience } & Web design & $0.704^{* *}$ & 0.026 & 14.758 \\
\hline & Ease of use & $0.786 * *$ & 0.033 & 17.157 \\
\hline & Perceived usefulness & $0.803^{* *}$ & 0.032 & 17.675 \\
\hline & E-service quality & $0.607^{* *}$ & 0.036 & 12.210 \\
\hline \multirow{4}{*}{$\begin{array}{ll}\text { Online } & \text { Shopping } \\
\text { Intention } & \end{array}$} & Web Trust & $0.229 * *$ & 0.038 & 3.565 \\
\hline & Perceived Risk & $-0.240 *$ & 0.029 & -3.889 \\
\hline & Security \& Private Protection & $0.576^{* *}$ & 0.042 & 7.993 \\
\hline & User Experience & $0.160^{* *}$ & 0.039 & 2.390 \\
\hline
\end{tabular}

Source: Author's Calculation; ${ }^{* *} p<0.01 * p<0.05$

The results revealed that the online intention to shopping was positively influenced by the web trust (beta=0.23), security \& private protection (beta=0.58), user experience (beta=0.16), and Security \& privacy protection (beta $=0.58$ ). Perceived risk (beta $=-0.24$ ) negatively influenced online shopping intention. 
INTERNATIONAL JOURNAL OF ACADEMIC RESEARCH IN BUSINESS AND SOCIAL SCIENCES

Vol. 9, No. 3, March, 2019, E-ISSN: 2222-6990 @ 2019 HRMARS

\section{Discussions}

The purpose of this research was to achieve a better understanding of the factors influencing online shopping intention and the adoption of online shopping in Oman. The discussions are structured based on the various determinants of online shopping intention.

Web trust: E-Word of mouth, interaction with shop, and POSE, e-Word of mouth determined the web trust. The findings of this study revealed that the buyers rely on reviews and rating of other buyers to get insights on the quality of the products, because of the nature of online shopping and the lack of interaction between buyers and sellers. The findings show high importance for both interactions with shop assistant and the availability of consumer reviews and product rating, and this indicates that shoppers return to consumer reviews and product rating, as they are unable to interact with shop assistants in-person. POSE is another attribute used to measure the influence of web trust on online shopping. The literature review revealed that as customers have more experience in online shopping activities, they are more likely to make online purchases (dos Santos and Fernandes 2011; Dai et al., 2014). Given the fact that the majority of the respondents were using the Internet for more than five years, rated their proficiency using Internet services as intermediate, and advanced, the results of this study are similar to the results of dos Santos and Fernandes (2011). Thus, the results regarding POSE, supports the literature that POSE influences web trust and thus influencing the online shopping intention. This study also revealed the Web trust positively influenced the Online shopping intention, which also supports the findings from the literature (Wu \& Kae 2015; Hsu et al., 2014). The overall relationship between web trust and POSE, interaction with shop and E-WoM holds true and, thus, the hypothesis $(\mathrm{H} 2)$ is supported and the influence of web trust in determining online shopping intention supports $\mathrm{H} 1$, in the sense that an increase in the web trust of an online store would result in an increase in online shopping intention.

Perceived Risk: Three attributes were measured to determine the relationship between the perceived risk and online shopping. The findings reveal that performance risk and convenience risk influenced the perceived risk more than financial risk and time risk, thus accepting Hypothesis $3(\mathrm{H} 3)$. The findings showed that these attributes are interrelated as one attribute may affect the other. Delivery time is a major concern for most respondents. As some products are not available locally, customers are compelled to buy products from international web-stores such as Amazon, eBay, and Alibaba. Products purchased from such international web-store require long delivery time. Another timerelated concern is the time wasted in finding reliable online stores. With the diversity of web-stores and products offered online, the increase in financial frauds and malicious websites, finding a reliable store requires more time, especially when online financial transactions are involved. Not being able to check the quality of the purchased merchandises is the other concern related to performance risk. With the proliferation of fake goods sold online as genuine and high-quality products, customers need to reduce these risks by checking the products in-person. Moreover, as customers purchase products from international web-stores, there is a possibility that products may be damaged during the shipping process and as such, returning those damaged products to the vendor may even cost more money than the original price of the product. In this situation, financial risk is another possibility. Hidden and unexpected costs may involve the costs of return the products, undeclared shipping costs, and unanticipated costume costs. Although the majority of respondents think that 
INTERNATIONAL JOURNAL OF ACADEMIC RESEARCH IN BUSINESS AND SOCIAL SCIENCES

Vol. 9, No. 3, March, 2019, E-ISSN: 2222-6990 @ 2019 HRMARS

online shopping is not pricey, even a bigger percentage of respondents viewed the possibility of buying overpriced products as a major concern. This concern can be attributed to the offerings of local websites, as their products are much higher as compared to large international web-stores. Thus, for the time being, customers have inclined to either sacrifice the convenience of enjoying cheaper prices or having more reliable web-stores choices supporting hypothesis $2(\mathrm{H} 2)$

Web Security and Privacy Protection: The study's findings revealed that both the secured payment options and protection of personal information determined the security and privacy protection. As respondents spent more money on online purchases and as their knowledge and experience increase with every interaction, the importance of securing their financial and personal information becomes a high priority for the majority of the respondents. The study found that about three-quarters of the respondents have shopped online at least once and have been using the Internet for more than 5 years. Although the study revealed the importance of both web security and privacy protection, it did not reveal whether the respondents take care of securing their financial and personal information on their end by implementing security measures of their own devices. The outcome of the analysis supports the importance of web security as examined in the literature review (Alharbi et al., 2013; Mpinganjira, 2015; Sam \& Sharma 2015; Shah \& Rao 2014; Shadkam, 2012; Topaloğlu 2012; Matic \& Vojvodic 2014). The result showed a positive relationship between web security and privacy protection and online shopping intention and thus hypothesis $5(\mathrm{H} 5)$ and hypothesis $6(\mathrm{H} 6)$ is supported.

User Experience: The importance of user experience is often underestimated by some web-stores. The examination of the results obtained through the questionnaire signifies the importance of good user experience. In general, different aspects may affect the user experience. All respondents agreed on the importance of the availability of detailed product specifications. This attribute correlates to the lack of direct interaction between buyers and sellers and the lack of the ability to check the quality in-person. It has been pointed out by Meera and Gayathiri (2015) in their research and according to Dyn's (2015), the findings support the literature review on the importance of loading speed of webstores' websites. The reasoning of this importance is that loading speed can give the users some assurance on the credibility of the store as it shows how the owners are serious about their online store by investing in the infrastructure of their web-store. Moreover, other attributes related to user experience are the perceived usefulness and perceived ease of use (Sam \& Sharma 2015; Wu \& Ke 2015). Regarding the perceived usefulness, all respondents and despite the difference in the degree of their agreement, have emphasized the importance of the availability of detailed product specifications. Time is one of the important factors in customers' online shopping decision, having all the required details about the products offered on an online store's website reduce the time required to find this information elsewhere. In addition, some online purchases may involve paying high amounts and having detailed specifications could give the customers some kind of assurance on whether or not the purchased goods will fit their needs and expectations. Ease of use attribute is another measurement used to determine the relationship between user experience and online shopping. Usually, UX importance is perceived in the reduction of the effort required to complete certain operations like finding the needed products and completing the payment process with as 
INTERNATIONAL JOURNAL OF ACADEMIC RESEARCH IN BUSINESS AND SOCIAL SCIENCES

Vol. 9, No. 3, March, 2019, E-ISSN: 222 2-6990 ¿ 2019 HRMARS

minimum clicks as possible. The findings revealed a positive relationship between user experience and online shopping. The findings support the hypotheses $(\mathrm{H6}), \mathrm{H}(7)$ and $(\mathrm{H} 8)$.

\section{Conclusion}

With the increase in e-commerce sales worldwide and the advancement in Information Technology, new factors associated with online shopping are introduced that may either refrain or encourage customers to shop online. Oman's B2C online shopping and transactions are on the increasing rapidly and a significant proportion of customers prefer online purchases. Customers, who prefer to choose to transact online, prefer non-Omani online shopping websites like Amazon, Alibaba, and UAE souq and henceforth, which the customers feel both safe and secure to transact. However, the delivery of the products through these online web stores reaches customers after scrutiny for security purpose and it takes a minimum of two weeks' time to reach the customers. This being the situation, Oman based online web stores do have a significant scope to penetrate the online shopper's B2C market share, provided if they can win the confidence of the online shoppers' in Oman. This research aimed to explore the online shoppers' intention and the factors influencing online shopping intention. Though multiple pieces of research are available across the globe, this study on 'online shopping' is an attempt to understand the factors underlying the adoption of online shopping in Oman's context. The study revealed that factors like web trust, perceived risk, web security and privacy protection, user experience determines the adoption of online shopping. Thus, this research contributes to the existing literature in the context of Oman and provides a strategical direction to the Oman-based online shopping websites by identifying the determinants of Online shopping intention of customers in Oman and based on which, these online shopping websites can reinvent their business model to attract the customers. Thus, an opportunity arises for the businesses to exploit as long as customers' expectations are met.

\section{References}

Alam, S.S., \& Yasin, N.M. (2010). An Investigation into the Antecedents of Customer Satisfaction of Online Shopping. Journal of Marketing Development and Competitiveness, 5(1), 71-78.

Ali, J. (2014). Consumer Behavior. Retrieved from http://www.slideshare.net/JahangirAli2/consumer-behavior-35928604

Almousa, M. (2011). The Influence of Risk Perception in Online Purchasing Behavior: a MultiDimensional Perspective. International Journal of Arts \& Sciences, 4(12), 373-82.

Bernard, E.K., \& Makienko, I. (2011). The Effects of Information Privacy and Online Shopping Experience in E-Commerce. Academy of Marketing Studies Journal, 15, 97-112.

Bentler, P.M. (1990). Comparative fit indexes in structural models. Psychological bulletin, 107(12), 238.

Browne, M.W., \& Cudeck, R. (1993). Alternative ways of assessing model fit. Sage focus editions, 154,136-136.

Dai, B., Forsythe, S., \& Kwon, W.S. (2014). The Impact of Online Shopping Experience on Risk Perceptions and Online Purchase Intentions: Does Product Category Matter?. Journal of Electronic Commerce Research, 15(11), 13-24. 
Santos, C. P. D., \& Fernandes, D. V. D. H. (2011). Perceptions of justice after recovery efforts in internet purchasing: the impact on consumer trust and loyalty toward retailing sites and online shopping in general. BAR-Brazilian Administration Review, 8(3), 225-246.

Dyn (2015). Global Consumer Online Shopping Expectations Available at: http://pages.dyn.com/rs/dyn/images/Dyn\%202015\%20ReportGlobal\%20Consumer\%200nline\%20Shopping\%20Expectations.pdf [Accessed 6 Feb 2019].

Forte, D., (2015). Why Customers Prefer Online Shopping. Available at: http://multichannelmerchant.com/infographics/why-customers-prefer-online-shopping06012015/ [Accessed 6 Feb 2019].

Habib, M. M., Pathik, B. B., \& Maryam, H. (2014). Research methodology-contemporary practices: guidelines for academic researchers. Cambridge Scholars Publishing.

Hsu, C. L., Chuan-Chuan Lin, J., \& Chiang, H. S. (2013). The effects of blogger recommendations on customers' online shopping intentions. Internet Research, 23(1), 69-88.

Hsu, M. H., Chuang, L. W., \& Hsu, C. S. (2014). Understanding online shopping intention: the roles of four types of trust and their antecedents. Internet Research, 24(3), 332-352.

Mubarak Alharbi, I., Zyngier, S., \& Hodkinson, C. (2013). Privacy by design and customers' perceived privacy and security concerns in the success of e-commerce. Journal of Enterprise Information ManageFdaiment, 26(6), 702-718.

Mubarak Alharbi, I., Zyngier, S., \& Hodkinson, C. (2013). Privacy by design and customers' perceived privacy and security concerns in the success of e-commerce. Journal of Enterprise Information Management, 26(6), 702-718.

Internet Live Stats (2016). Retrieved from http://www.internetlivestats.com/internet-users/oman/ Jawa, H. A., \& Chaichi, K. (2015). Factors Influencing Consumer Behavior Towards Online Shopping in Saudi Arabia. International Journal of Multicultural and Multireligious Understanding, 2(4), 110.

Jöreskog, K. G., \& Sörbom, D. (1993). LISREL 8: Structural equation modeling with the SIMPLIS command language. Scientific Software International.

Schermelleh-Engel, K., Moosbrugger, H., \& Müller, H. (2003). Evaluating the fit of structural equation models: Tests of significance and descriptive goodness-of-fit measures. Methods of psychological research online, 8(2), 23-74.

Kim, S. H., \& Byramjee, F. (2014). Effects Of Risks On Online Consumers' Purchasing Behavior: Are They Risk-Averse Or Risk-Taking?. Journal of Applied Business Research, 30(1), 161.

Kim, J., \& Lennon, S. J. (2013). Effects of reputation and website quality on online consumers' emotion, perceived risk and purchase intention: Based on the stimulus-organism-response model. Journal of Research in Interactive Marketing, 7(1), 33-56.

Kim, H., \& Song, J. (2010). The quality of word-of-mouth in the online shopping mall. Journal of Research in Interactive Marketing, 4(4), 376-390.

Knemeyer, D. and Svoboda, E., (2007). User Experience - UX. Available at: https://www.interactiondesign.org/literature/book/the-glossary-of-human-computer-interaction/user-experienceux [Accessed 24 Feb 2019]. 
INTERNATIONAL JOURNAL OF ACADEMIC RESEARCH IN BUSINESS AND SOCIAL SCIENCES

Vol. 9, No. 3, March, 2019, E-ISSN: 222 2-6990 @ 2019 HRMARS

Köksal, Y., \& Penez, S. (2015). An investigation of the important factors influence web trust in online shopping. Journal of Marketing and Management, 6(1), 28.

Kuada, J. (2012). Research Methodology: A Project Guide for University Students. Frederiksberg, DNK: Samfundslitteratur Press. Available at: http://site.ebrary.com/lib/majan/detail.action?doclD=10636329

Kwon, W. S., \& Noh, M. (2010). The influence of prior experience and age on mature consumers' perceptions and intentions of internet apparel shopping. Journal of Fashion Marketing and Management: An International Journal, 14(3), 335-349.

Lingytè, M., Valsamidis, S., Mitsinis, N., \& Polychronidou, P. (2011). E-commerce behaviour of Lithuanian and Greek women. Intellectual Economics, 5(1), 85-98.

MasterCard, (2015). Online Shopping Behaviour Study. Available at: http://newsroom.mastercard.com/mea/digital-press-kits/online-shopping-behaviour-study2015/ [Accessed 24 Feb 2019].

Mathew, M., (2013). Online Shopping Habits Questionnaire. Available at: http://www.slideshare.net/manuelmathew1/online-shopping-habits-among-students-andteachers-of-st [Accessed 24 Feb 2019].

Matic, M., \& Vojvodic, K. (2013). Customer-Perceived Insecurity of Online Shopping Environment. International Review of Management and Marketing, 4(1), 59-65.

Meera, V., \& Gayathiri, P. (2015). Digital Marketing and Enhancing Consumer Experience in Online Shopping. The International Journal of Business \& Management, 3(6), 186.

MENA bytes (2019). Ecommerce in MENA expected to reach $\$ 28.5$ billion by 2022: Retrieved from https://www.menabytes.com/ecommerce-mena-2022/

Mordorintelligence.com (2019). E-commerce Market in Oman - Market trend, Growth and Opportunities (2016 - 2021) Retrieved from https://www.mordorintelligence.com/industryreports/e-commerce-market-in-oman.

Morville, P. (2004). User Experience Design. Available at: http://semanticstudios.com/user_experience_design/ [Accessed 24 Feb 2019].

Mpinganjira, M. (2015). An investigation of perceived service quality in online shopping: $A$ hierarchical approach. Journal of Applied Business Research, 31(1), 115.

Mubarak Alharbi, I., Zyngier, S., \& Hodkinson, C. (2013). Privacy by design and customers' perceived privacy and security concerns in the success of e-commerce. Journal of Enterprise Information Management, 26(6), 702-718.

Passyn, K. A., Diriker, M., \& Settle, R. B. (2011). Images of online versus store shopping: Have the attitudes of men and women, young and old really changed. Journal of Business \& Economics Research, 9(1), 99-110.

Peters, J., Howard, K., \& Sharp, J. (2012). Management of a Student Research Project. Abingdon, GB: Gower. Available at: http://site.ebrary.com/lib/majan/detail.action?doclD=10211037

Pi, S. M., \& Sangruang, J. (2011). The perceived risks of online shopping in Taiwan. Social Behavior and Personality: an international journal, 39(2), 275-286.

Qureshi, H. A., Fatima, R., \& Sarwar, A. (2014). BARRIERS TO ADOPTION OF ONLINE SHOPPING IN PAKISTAN. Science International, 26(3). 
Racherla, P. (2008). Factors influencing consumers' trust perceptions of online product reviews: A study of the tourism and hospitality online product review systems. Temple University.

Rodgers, W. (2010). E-commerce issues addressed in a throughput model. Nova Science Publishers. Retrieved from http://site.ebrary.com/lib/majan/reader.action?ppg=16\&doclD=10670944\&tm=146256983 1953

Rose, S., Clark, M., Samouel, P., \& Hair, N. (2012). Online customer experience in e-retailing: an empirical model of antecedents and outcomes. Journal of Retailing, 88(2), 308-322.

Sam, C. Y., \& Sharma, C. (2015). An Exploration into the Factors Driving Consumers in Singapore towards or away from the Adoption of Online Shopping. Global Business \& Management Research, 7(1).

Shadkam, M. (2012). An Empirical Study on Influence Factors Of Online Purchasing. International Journal of Arts \& Sciences, 5(1), 479.

Shah, A. B., \& Rao, M. G. (2014). A study on factors affecting online shopping behaviour in Gujarat. International Journal of Applied Services Marketing Perspectives, 3(2), 964.

Sheikha, A.M. (2019, January 1). 45 percent of shoppers in Oman buy online. Times of Oman. Retrieved from https://timesofoman.com/article/674359

Topaloğlu, C. (2012). Consumer motivation and concern factors for online shopping in Turkey. Asian Academy of Management Journal, 17(2), 1-19.

Vinod, A., Subhash, D. A., Kumar, T. S., \& Shameem, M. (2015). Examining role of perceived customer value in online shopping. Indian Journal of Economics and Business, 14(2), 235-244.

World pay (2016) Top 4 user experience issues for retail shoppers Retrieved from https://www.worldpay.com/global/insight/articles/2016-03/top-4-user-experience-issuesretail-shoppers

Wu, W. Y., \& Ke, C. C. (2015). An online shopping behavior model integrating personality traits, perceived risk, and technology acceptance. Social Behavior and Personality: an international journal, 43(1), 85-97.

Zarco, T. H. (2015). Effects of Online Review Valence on Consumer Attitudes and Behavioral Intentions. Philippine Management Review, 22.

\section{About the Authors}

Hamed Khalfan Hamed AL-Shukri is a BA Business Administration graduate of Majan University College, Oman. Hamed currently works as a software engineer in an IT firm. The author can be contacted at hamed.alshukri@qomrah.om

Udayanan is an Assistant Professor in the Faculty of Business Management at Majan University College. The author can be contacted at pappusamy.udhaynan@majancollege.edu.om

Acknowledgement: This research is an extension of the undergraduate graduate research project of Hamed Khalfan Hamed AL-Shukri, a graduate of Majan University College, Oman (First author). 